\section{Loss of Apc in vivo immediately perturbs Wnt signaling, differentiation, and migration}

\author{
Owen J. Sansom, ${ }^{1}$ Karen R. Reed, ${ }^{1}$ \\ Anthony J. Hayes, ${ }^{1}$ Heather Ireland, ${ }^{2}$ \\ Hannah Brinkmann, ${ }^{1}$ Ian P. Newton, ${ }^{3}$ \\ Eduard Batlle, ${ }^{4}$ Patricia Simon-Assmann, ${ }^{5}$ \\ Hans Clevers, ${ }^{4}$ Inke S. Nathke, ${ }^{3}$ Alan R. Clarke, ${ }^{1,6}$ \\ and Douglas J. Winton ${ }^{2}$ \\ ${ }^{1}$ School of Biosciences, University of Cardiff, Cardiff CF10 \\ 3US, Wales; ${ }^{2}$ Cancer Research UK Department of Oncology, \\ Cambridge CB2 2XY, UK; ${ }^{3}$ School of Life Sciences, University \\ of Dundee, Dundee DD1 5EH, Scotland; ${ }^{4}$ Hubrecht \\ Laboratory, 3584 CT Utrecht, The Netherlands; ${ }^{5}$ INSERM \\ U381, Strasbourg, France.
}

Although Apc is well characterized as a tumor-suppressor gene in the intestine, the precise mechanism of this suppression remains to be defined. Using a novel inducible Ahcre transgenic line in conjunction with a loxPflanked Apc allele we, show that loss of Apc acutely activates Wnt signaling through the nuclear accumulation of $\beta$-catenin. Coincidentally, it perturbs differentiation, migration, proliferation, and apoptosis, such that Apc-deficient cells maintain a "crypt progenitor-like" phenotype. Critically, for the first time we confirm a series of Wnt target molecules in an in vivo setting and also identify a series of new candidate targets within the same setting.

Supplemental material is available at http://www.genesdev.org.

Received October 3, 2003; revised version accepted April 19, 2004.

The APC gene encodes the adenomatous polyposis coli tumor-suppressor protein, the germline mutation of which characterizes Familial Adenomatous Polyposis (FAP), an autosomal syndrome characterized by multiple colorectal lesions (Kinzler et al. 1991). Inactivation of APC is also recognized as a key early event in the development of sporadic colorectal cancers. By targeting $\beta$-catenin for degradation and thereby regulating Wnt signaling (Kinzler and Vogelstein 1996; Morin et al. 1997) APC has been implicated in a range of cellular functions including adhesion, apoptosis, and cell cycle control (Bienz and Clevers 2000). APC may also have a Wnt-independent role in cell migration and chromosomal stability (Näthke et al. 1996; Fodde et al. 2001;

[Keywords: Apc; Wnt signaling; intestine; conditional; apoptosis] ${ }^{6}$ Corresponding author.

E-MAIL clarkear@cf.ac.uk; FAX 44-0-2920-874116.

Article and publication are at http://www.genesdev.org/cgi/doi/10.1101/ $\operatorname{gad} .287404$.
Kaplan et al. 2001). However, the phenotype accompanying loss of APC appears to be context dependent, with different consequences in different cell types and at different stages of neoplastic progression (e.g., Gallagher et al. 2002; Harada et al. 2002). Hence, the role of APC in normal intestinal epithelium and the primary consequences of its loss are not known, and as a consequence, neither is the precise sequence of events (both molecular and cellular) arising from its loss to the development of overt preneoplastic lesions.

Cell renewal within the intestinal epithelium is highly regulated and position dependent. Absorptive cells generated within intestinal crypts migrate upward until they either die by apoptosis or are shed into the gut lumen, a process that takes $3-5 \mathrm{~d}$ (Potten et al. 1997). A central role for Apc in controlling this process has been suggested by two recent studies. First, blockade of Wnt signaling in cultured cells has been used to implicate normal Wnt signaling in imposing a crypt progenitor phenotype (van de Wetering et al. 2002). Second, Wnt signaling has been shown to influence paneth cell positioning in the crypt through transcriptional activation of EphB2 and EphB3 (Batlle et al. 2002). Furthermore, a role for Apc in cell migration has been suggested based on its complex association with, and effect on, cytoskeletal proteins.

Here, for the first time, we determine the immediate consequences of Apc loss in otherwise normal murine epithelium. Inactivation of Apc leads to the rapid nuclear relocalization of $\beta$-catenin, a coincident gross change in the transcriptome, and a coordinated series of cellular changes, including failure to migrate and differentiate. Together, these effects allow evasion of the normal ablative fate.

\section{Results and Discussion}

Loss of Apc perturbs intestinal pathology and causes morbidity after $5 d$

To investigate the phenotype of conditional deletion of Apc, mice bearing a lox-flanked $A p c$ allele were crossed onto a novel inducible cre transgenic background, which uses the Cyp1A promoter to deliver inducible cre expression in the intestine (details of this AhCre transgene are given in Supplementary Fig. 1). $C r e^{+} A p c^{f l / f 1}$ and $\mathrm{Cre}^{+} \mathrm{Apc}^{+/+}$progeny were identified and were subjected to four daily injections of $\beta$-napthoflavone at $8-10 \mathrm{wk}$ of age, resulting in virtually $100 \%$ intestinal recombination as scored through the Rosa26R allele (Supplementary Fig. 1). On day 5, $\mathrm{Cre}^{+} A p c^{f l / f 1}$ mice became visibly ill and were killed. In contrast, $\mathrm{Cre}^{+} A \mathrm{Ac}^{+/+}$mice showed no symptoms of illness.

Histological analysis of the organs from the napthoflavone-induced $C r e^{+} A p c^{f l / f 1}$ mice revealed altered cryptvillus architecture such that a discrete crypt was no longer identifiable, but morphologically atypical "cryptlike" cells now occupied the majority of the crypt-villus axis (Fig. 1a,b). Cells were more densely packed than in control mice, and the upper extent of phenotypic change was readily identifiable from hematoxylin-and-eosinstained material (Fig. 1a,b). To confirm that the pattern of atypical histology was coincident with the pattern of 


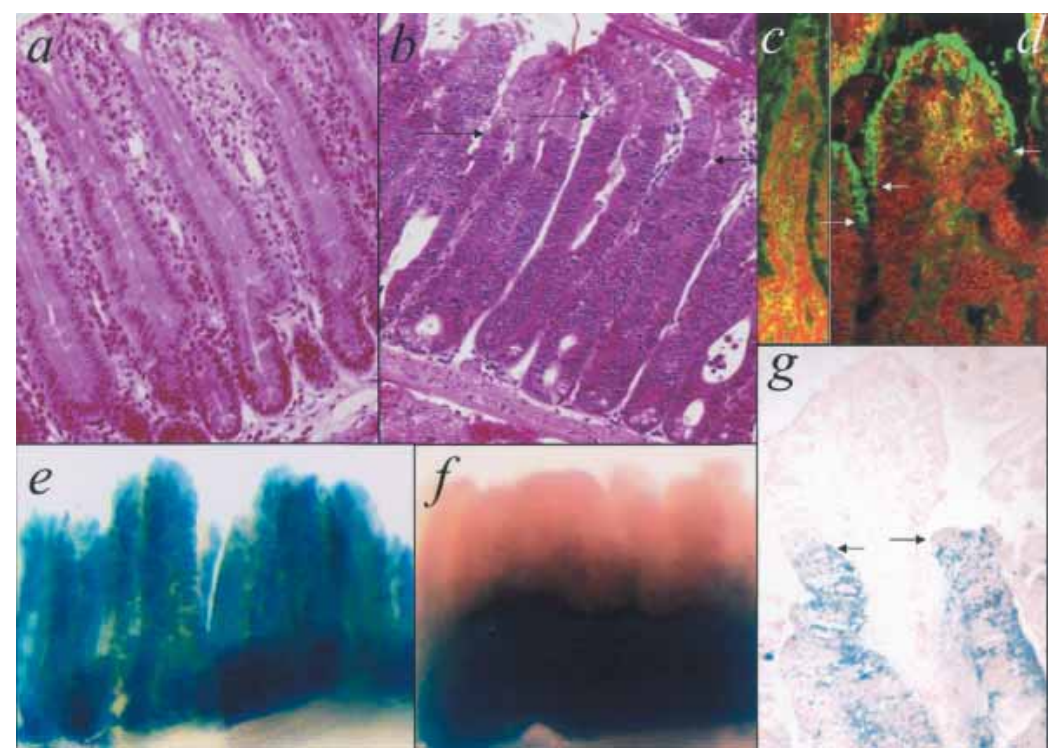

Figure 1. Changes in intestinal crypt pathology $5 \mathrm{~d}$ after the first injection of the cre-inducing agent $\beta$-napthoflavone. $(a, b)$. Hematoxylin-and-eosin-stained sections for control, induced $\mathrm{Cre}^{+} \mathrm{Apc}^{+/+}(a)$, and induced $\mathrm{Cre}^{+} \mathrm{Apc} c^{f l / f 1}(b)$ mice, showing an enlarged crypt-like region in the induced $\mathrm{Cre}^{+} \mathrm{Apc}^{f l / f l}$ mice. $(c, d)$ Apc immunofluorescence in induced $\mathrm{Cre}^{+} \mathrm{Apc}^{+/+}(c)$ and in induced $\mathrm{Cre}^{+} \mathrm{Apc}^{f 1 / f 1}(d)$ mice. Loss of Apc protein was observed in all morphologically atypical cells (below the arrow) in $\mathrm{Cre}^{+} A p c^{f 1 / f l}$ mice. Apc staining was observed in unrecombined morphologically normal cells in the villus (above the arrow). $(e, f)$ Wholemount preparations of intestines stained for lacZ activity to report cre-mediated recombination at the Rosa26R locus. Recombined control cells completely repopulate the crypt-villus axis (e) but fail to do so in the absence of Apc (f). $(g)$ Sectioned material from $f$ confirming that the pattern of recombination scored by LacZ activity directly overlays the pattern of histological change. Note that the staining for $\beta$-galactosidase exactly complements the Apc staining, with only the morphologically atypical cells (below the arrows) staining for $\beta$-galactosidase. For all panels, arrows indicate the point of demarcation between normal and atypical histology.

Apc inactivation, sections were stained for Apc expression (Fig. 1c,d). In induced $C r e^{+} A p c^{f 1 / f 1}$ mice, the pattern of loss of Apc directly overlaid the pattern of histological change. Analysis of $\mathrm{Cre}^{+} \mathrm{Apc}^{+/+}$mice additionally transgenic for the Rosa26R reporter locus confirmed that $5 \mathrm{~d}$ is a sufficient period for repopulation of the entire cryptvillus axis by wild-type cells (Fig. 1e). In contrast, complete repopulation did not occur in $\mathrm{Cre}^{+} A p c^{f l / f 1} \operatorname{Rosa} 26 \mathrm{R}$ mice, as evidenced by the pattern of $\beta$-galactosidase staining, which directly overlay the aberrant crypt pathology and excluded the retained unrecombined villus (Fig. 1f,g). This demonstrates both aberrant repopulation of the crypt-villus axis by Apc deficient cells and failure of the normal process of villus cell removal.

\section{Loss of Apc alters the normal pattern of differentiation and proliferation}

We next examined how loss of Apc had perturbed differentiation using a number of histological markers (Fig. 2). Apc-deficient cells were no longer capable of expressing the villus cell markers alkaline phosphatase (Fig. 2a,b) or Villin (Supplementary Fig. 2). Figure 2d shows that Goblet cells are lost in the absence of Apc and that no binding is observed for the Pokeweed lectin. Despite this latter observation, lysozyme staining did identify Paneth cells, but these were now distributed throughout the crypt-like area, rather than being confined to their normal position at the crypt base (Fig. 2f). These observa- tions therefore reflect perturbed positioning and also possibly perturbed differentiation of the Paneth cells. Notably, the distribution of these Paneth-like cells directly parallels that observed in EphB3 ${ }^{-/-}$mice (Batlle et al. 2002) and is presumably a consequence of alterations in the EphB gradient. We also evaluated the relative proportion of enteroendocrine cells, finding them to be reduced in the aberrant areas (Supplementary Fig. 2; 1.5\% in control crypts compared with $0.8 \%$ in induced $\mathrm{Cre}^{+} A p c^{f 1 / f 1}$ crypts, $p=0.04$, Mann Whitney U test).

Changes were also observed in the expression patterns of a number of extracellular matrix proteins, including laminin $\alpha 1$ and $\alpha 2$, laminin $\gamma 2$, tenascin, and perlecan (Supplementary Fig. 2). These findings indicate that loss of Apc in the epithelium also has an immediate effect on the surrounding mesenchyme.

Previous studies have characterized a defined proliferative zone within the normal crypt. To test whether this zone was altered, mice were injected with BrdU and killed $2 \mathrm{~h}$ later (Fig. 3a,c). The location and proportion of cells in $S$ phase was then scored. In control mice, cycling cells were confined to the expected mid crypt region (Fig. 3a,e). However, induced $\mathrm{Cre}^{+} A p c^{f 1 / f 1}$ crypts showed a $45 \%$ increase in the proliferation index $\left(\mathrm{Cre}^{+} \mathrm{Apc}^{+/+}\right.$crypts $23.6 \% \pm$ $2.3 \%$ standard error, $C r e^{+} A p c^{f 1 / f 1}$ crypts $34.4 \% \pm 2.0 \%, p=0.04$, Mann Whitney, $n=3$ ), with proliferation now occurring independently of position (Fig. 3c,f). Staining with $\mathrm{Mcm} 2$ antibody further supported these observations, as it marked an expanded zone of proliferative competence in the mutants (Fig. 2g,h).

\section{Apc deficiency abrogates migration}

We next tracked the pattern of migration of BrdU-labeled cells by killing mice $24 \mathrm{~h}$ after BrdU exposure (BrdU is bioavailable for $<2 \mathrm{~h}$, effectively "tagging" those cells in $\mathrm{S}$ phase; Fig. $3 \mathrm{~b}, \mathrm{~d})$. In induced $\mathrm{Cre}^{+} \mathrm{Apc^{+/+ }}$ mice, the average distance of BrdU-positive cells from the base of the crypt increased by $60 \mu \mathrm{m}$ at $24 \mathrm{~h}$ /control average distance at $2 \mathrm{~h}, 32.73 \mu \mathrm{m} \pm 3.31 \mu \mathrm{m} \mathrm{S}$.E., and at $24 \mathrm{~h}, 98.64$ $\mu \mathrm{m} \pm 3.49 \mu \mathrm{m} ; \mathrm{Cre}^{+} A p c^{f l / f 1}$ mice at $2 \mathrm{~h}, 92.3 \mu \mathrm{m} \pm 11.56$ $\mu \mathrm{m}$, and at $24 \mathrm{~h}, 92.86 \mu \mathrm{m} \pm 7.41 \mu \mathrm{m})$. In the induced $C r e^{+} A p c^{f l / f 1}$ mice, the average value did not change, nor did the cumulative distribution of labeled nuclei (Fig. 3f).

We therefore show that inactivation of Apc completely abrogates migration along the crypt-villus axis. This change provides a ready mechanism both for the selective retention of somatically arising Apc mutant cells and for the acquisition of further genetic changes. It is, however, clear that the effect of Apc deficiency extends beyond migration, as deficiency also leads to the production of daughter cells that have many properties of premalignant cells, including both failed differentiation and increased proliferation.

The changes observed in proliferation were accompanied by enhanced levels of cell death, with elevated levels of apoptosis in the $C r e^{+} A p c^{f l / f 1}$ mice either scored 


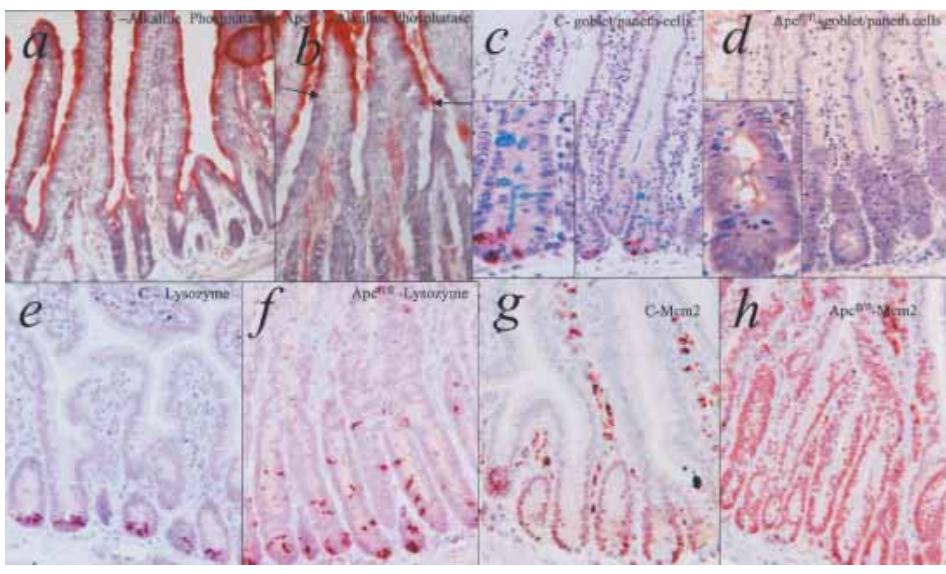

Figure 2. Perturbation of differentiation in the absence of Apc. $(a, b)$ Immunohistochemical staining for alkaline phosphatase in control, induced $\mathrm{Cre}^{+} \mathrm{Apc}^{+/+}$ mice $(a)$ and induced $\mathrm{Cre}^{+} A p c^{f l / f l}$ intestines $(b)$. Apc mutant cells do not express the villus marker alkaline phosphatase, with the arrow indicating demarcation between the residual wild-type and recombined Apc-deficient cells. $(c, d)$ Staining for Goblet cells (blue cells stained with alcian blue) and Paneth cells (red cells stained with Pokeweed lectin) in the crypt-villus axis of control induced $\mathrm{Cre}^{+} A p \mathrm{c}^{+/+}$mice $(c)$ and induced $\mathrm{Cre}^{+} A p c^{f l / f 1}$ intestines $(d)$. Insets show detail of crypts. No Goblet or Paneth cell staining was observed in the induced $\mathrm{Cre}^{+} \mathrm{Apc} \mathrm{c}^{\mathrm{fl} / \mathrm{fl}}$ mice. $(e, f)$ Staining for lysozyme in induced $\mathrm{Cre}^{+} \mathrm{Apc}^{+/+}(e)$ and induced $\mathrm{Cre}^{+} \mathrm{Apc}^{f 1 / f 1}(f)$ mice. Lyzozyme positivity is confined to the base of the crypt in the controls but is distributed throughout the crypt-like region in the induced $\mathrm{Cre}^{+} A p c^{f l / f l}$ mice. $(g, h) \mathrm{Mcm} 2$ staining with positivity restricted to the crypt within the induced $\mathrm{Cre}^{+} \mathrm{Apc}^{+/+}$mice $(g)$ but extending through the aberrant crypt structure in the induced $\mathrm{Cre}^{+} A p c^{f 1 / f 1}$ mice $(h)$.

histologically (control crypts, $3.5 \% \pm 0.45 \%$ S.E.; $\operatorname{Cre}^{+} A p c^{f 1 / f 1}, 11.1 \% \pm 1.2 ; p=0.01$, Mann Whitney, $n=5$ ) or identified immunohistochemically with an antibody against active caspase-3 (Fig. 3g,h). These findings contrast with previous studies (Bedi et al. 1995) that have reported reduced levels of apoptosis in colorectal cancer. This is presumably a reflection of our focus on the primary consequences of Apc loss within a naive epithelium, rather than on the adapted behavior of a neoplastic population. There appear three possible explanations for the increase we observe in apoptosis. First, this may be a direct consequence of c-Myc up-regulation in a manner analogous to that demonstrated in pancreatic $\beta$ cells (Pelengaris et al. 2002). Second, this may result from altered matrix interactions that subsequently stimulate an anoikis signal. In support of this, we see changes in the patterns of expression of many of the laminins, of MMP7, and of the antiadhesive molecule tenascin (Probstmeier et al. 1990). Third, mitosis may be aberrant, as Apc has been implicated in the formation of mitotic spindles (Fodde et al. 2001; Kaplan et al. 2001). Indeed, many of the apoptotic figures we observed were large, a phenomenon previously interpreted to reflect death of $4 \mathrm{~N}$ cells at a G2/M checkpoint (Merritt et al. 1997).

Elevated apoptosis and enhanced proliferation have been described previously in studies that have altered $\beta$-catenin/TCF4 signaling in intestinal epithelium (Wong et al. 1998, 2002). However, the changes we identify are far more extensive, including, in addition, gross changes in differentiation and migration. The enhanced perturbation associated with Apc loss may reflect differences in the timing, extent, or localization of $\beta$-catenin up-regulation or, indeed, $\beta$-catenin independent effects.

Loss of Apc leads to rapid nuclear localization of $\beta$-catenin and allows identification of Wnt targets in an in vivo setting

We next investigated $\beta$-catenin levels within the $\mathrm{Cre}^{+} A p c^{f l / f 1}$ tissue at day 5. There was no increase in total $\beta$-catenin in the $C r e^{+} A p c^{f 1 / f 1}$ samples (Fig. 4a). However, levels of dephosphorylated $\beta$-catenin were moderately elevated and, crucially, $\beta$-catenin relocalized to the nuclei in the $\mathrm{Cre}^{+} A p c^{f l / f 1}$ tissue (Fig. 4c; Supplementary Fig. 3). To more precisely define the time scale of nuclear relocalization, immunohistochemical analyses were also performed at days 1, 2, 3, and 4 following induction of the cre recombinase (Supplementary Fig. 3). This analysis showed that relocalization occurred at day 3 , and this was coincident with the observed onset of changes in morphology, proliferation, and apoptosis.

To test whether nuclear $\beta$-catenin was activating transcription of its known target genes, microarray analysis was performed using the af-
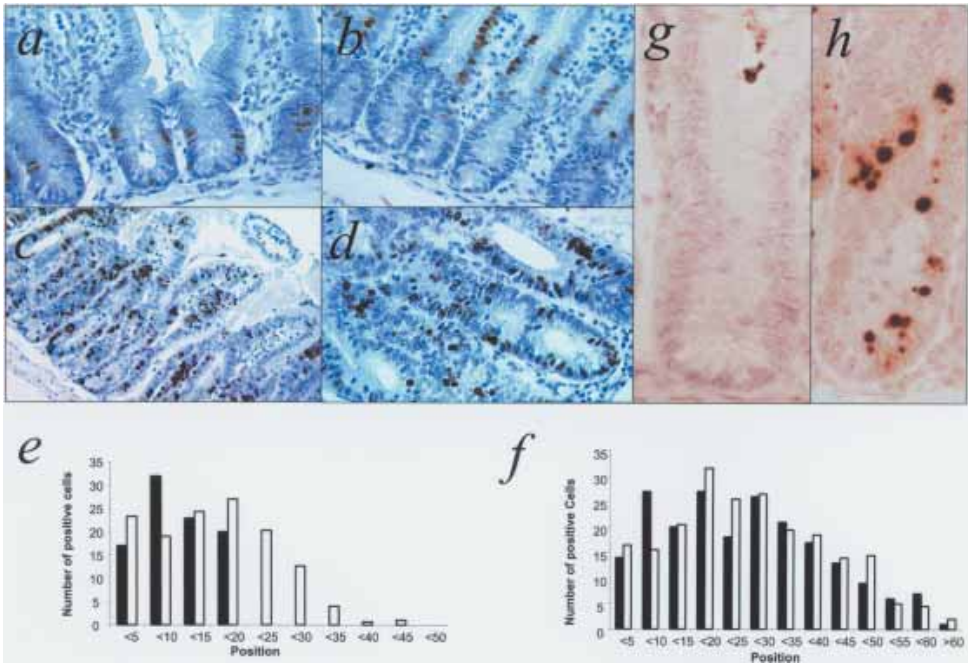

Figure 3. Altered proliferation, migration, and apoptosis in the absence of Apc. $(a-f)$ BrdU staining in control and Apc-deficient intestinal epithelium. (a) BrdUpositivite cells in wild-type-induced $\mathrm{Cre}^{+} \mathrm{Apc}^{+/+}$crypts $2 \mathrm{~h}$ following BrdU injection are confined to a proliferative zone within the crypt. (b) The position of BrdUpositive cells in crypt-villus axis of control, induced $\mathrm{Cre}^{+} \mathrm{Apc}^{+/+}$mice $24 \mathrm{~h}$ after BrdU injection, indicating migration of labeled cells onto the villus. (c) BrdU staining in induced $\mathrm{Cre}^{+} \mathrm{Apc} c^{f l / f 1}$ epithelium $2 \mathrm{~h}$ after BrdU injection show that positively stained cells are present throughout the entire aberrant crypt-like structure. $(d)$ BrdU staining $24 \mathrm{~h}$ after injection of BrdU in induced $\mathrm{Cre}^{+} A p c^{f 1 / f 1}$ intestinal epithelium. (e) Position of BrdU-positive cells within the control crypt-villus axis at $2 \mathrm{~h}$ (black bars) and $24 \mathrm{~h}$ (open bars). Position 0 represents the base of the crypt. Note the increase in position at $24 \mathrm{~h}$, reflecting migration. $(f)$ Position of BrdU cells within the crypt-like structure in induced $\mathrm{Cre}^{+} A p c^{\mathrm{fl} / \mathrm{fl}}$ mice at $2 \mathrm{~h}$ (black bars) and $24 \mathrm{~h}$ (open bars). Unlike in the controls, no migration of labeled cells is evident. $(g, h)$ Increased apoptosis in Apc mutant crypts. Immunohistochemical staining of active caspase 3 in induced $\mathrm{Cre}^{+} \mathrm{Apc}^{+/+}$mice $(g)$ and induced $\mathrm{Cre}^{+} A p c^{f l / f 1}$ mutant crypts $(h)$. This staining confirmed apoptosis counts from H\&E-stained sections that showed significantly increased apoptosis in Apc deficient crypts $(11.1 \% \pm 1.2 \%)$ compared with control crypts $(3.5 \% \pm 0.45 \% ; p=0.01$; Mann Whitney, $n=5)$. 

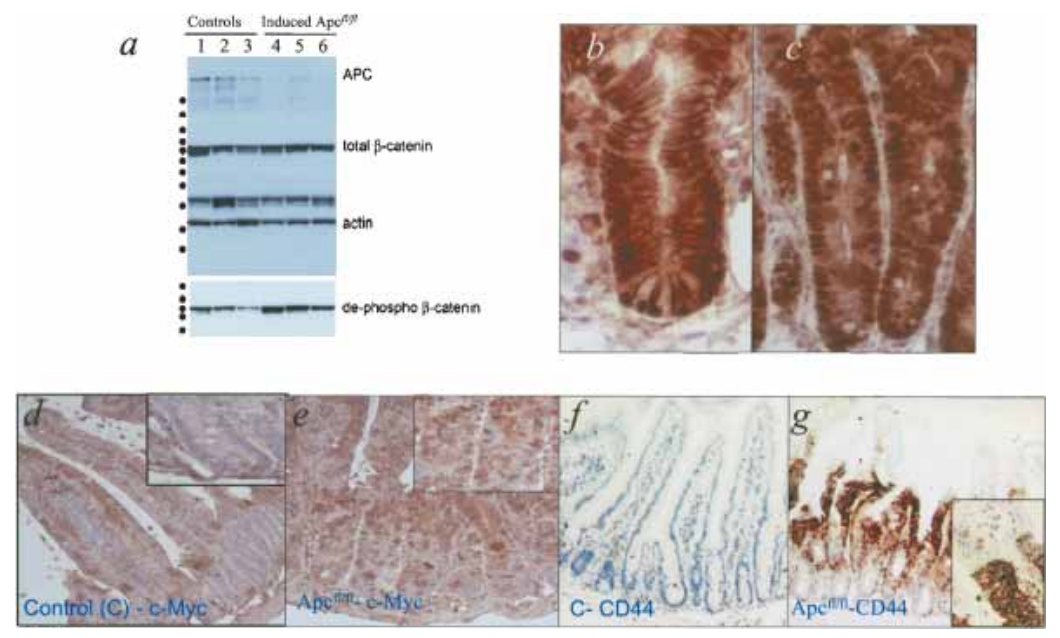

Figure 4. (a) Immunoblasts show the levels of Apc, $\beta$-catenin, and dephosphorylated $\beta$-catenin. Equal amounts of protein from induced control $\mathrm{Cre}^{+} \mathrm{Apc}^{+/+}$, uninduced $\mathrm{Cre}^{+} A p c^{f l / f l}$, and induced $\mathrm{Cre}^{+} A p c^{f l / f l}$ mice were separated on a $4 \%-12 \%$ gradient gel and probed with antibodies against Apc, $\beta$-catenin, actin, and dephospho- $\beta$-catenin as shown. Probing with dephospho- $\beta$-catenin was performed first and the blot stripped before it was reprobed with the antibody that detects all $\beta$-catenin so that these two images reflect identical samples. No image processing was performed on the films, and they are shown in their original appearance. Although the total amount of $\beta$-catenin is not grossly different between the different samples, the amount of dephosphorylated $\beta$-catenin is increased after inactivation of Apc in the tissue obtained from induced $\mathrm{Cre}^{+} \mathrm{Apc}^{f l / f l}$ mice, whereas detectable Apc levels drop significantly. (Lanes 1,2) Induced $\mathrm{Cre}^{+} \mathrm{Apc}^{+/+}$. (Lane 3) Noninduced $\mathrm{Cre}^{+} \mathrm{Apc}^{f l / f 1}$. (Lanes 4-6) Induced $\mathrm{Cre}^{+} \mathrm{Apc}{ }^{f l / f 1}$. The migration of proteins with molecular weights of $220,160,120,100,90,80,60,50,40$, 30 , and $20 \mathrm{kDa}($ top $)$ and 120,100, 9080 , and $50 \mathrm{kDa}$ (bottom) are indicated to the left of the blots. $(b, c)$ Increased nuclear $\beta$-catenin staining in crypts. $(b) \beta$-catenin staining in control crypts $5 \mathrm{~d}$ after the first of four inductions with $\beta$-napthoflavone, showing nuclear staining confined to the cells at base of the crypts. $(c)$ Nuclear $\beta$-catenin staining observed throughout the whole of the aberrant structure in induced $\mathrm{Cre}^{+} A p c^{f l / f 1}$ mice $5 \mathrm{~d}$ after induction. $(d, e)$ Immunohistochemical confirmation of c-Myc up-regulation. (d) Staining for c-Myc in control $\mathrm{Cre}^{+} \mathrm{Apc}^{+/+}$intestine at day 5. The inset shows crypt detail; note the absence of nuclear staining. (d) Nuclear up-regulation of c-Myc in the induced $\mathrm{Cre}^{+} \mathrm{Ap} c^{f l / f l}$ mice, with inset showing crypt detail. $(f, g)$ Immunohistochemical confirmation of CD44 up-regulation. $(f)$ No detectable CD44 staining in control $\mathrm{Cre}^{+} \mathrm{Apc}^{+/+}$intestines at day 5. $(\mathrm{g}) \mathrm{Up}$-regulation of CD44 in the induced $\mathrm{Cre}^{+} A p \mathrm{c}^{f l / f 1}$ mice. The inset shows detail.

fymetrix U74A chip. RNA samples were derived from sibling $\mathrm{Cre}^{+} A p c^{f l / f 1}$ and $\mathrm{Cre}^{+} A \mathrm{Ac}^{+/+}$mice given four daily injections of $\beta$-napthoflavone and killed at days 4 and 5 . The most significantly up- and down-regulated genes identified by SAM analysis at day 5 are shown in Supplementary Figure 4 . Of the 100 most significantly up-regulated genes, 10 have been previously associated with Wnt signaling (either directly or through recent arrays that had examined targets of the $\beta$-catenin/TCF 4 complex).

At the earlier 4-d timepoint, array analysis was performed using the larger MOE430A Affymetrix chipset (Supplementary Table 1). Of the comparable genes upregulated at day 5, 45 of 47 showed increases, of which 36 were in excess of twofold. These 36 included $c-M y c$, $C D 44$, Tiam 1, Sema3c, and EphB3, all of which were confirmed changes at day 5 . These data are, therefore, consistent with the notion that these are important early changes following nuclear relocalization of $\beta$-catenin. Use of the larger chip set also revealed up-regulation of other Wnt target genes at day 4, including Sox17 and Axin2 (Lustig et al. 2002).

To validate the results obtained from the microarray analysis, we examined the expression pattern of a subset of dysregulated genes. Up-regulation of CD44, C-Myc, laminin $\gamma 2$, EphB2, and EphB3 was confirmed immunohistochemically in the Apc-deficient tissue (Figs. 4d-g, $5 \mathrm{a}-\mathrm{d}$; Supplementary Fig. 2). Expression of the EphrinB2 ligand, which is normally restricted to the top of the crypts and villi (Fig. 5f), was reduced in concordance with the reduction in villus differentiation in the $\mathrm{Cre}^{+} A p c^{f l / f 1}$ tissue (Fig. 5g). These data therefore confirm, in an in vivo setting, many of the targets of Wnt signaling that have been implicated from in vitro studies (e.g., Bienz and Clevers 2000; van de Wetering et al. 2002). These include up-regulation of CD44, c-Myc, MMP-7 (matrilysin), $\gamma-2$ laminin, Sema3c (confirmed by RT-PCR; Supplementary Fig. 4) Ets-2, EphB2, EphB3, and GPR49. The array analysis also indicated up-regulation of a series of genes that either interact with CD44 or are targets of CD44. These include MMP-7, TIAM1, FGF4 and its receptor, and TASR-2. The upregulation of TIAM1 (confirmed by RTPCR; Supplementary Fig. 4) is particularly interesting, as TIAM1 has been shown to mediate Ras signaling. Indeed, mice deficient in TIAM1 are resistant to Ras-induced skin tumors (Malliri et al. 2002).

Batlle et al. (2002) have shown that deficiency of EphB3 leads to abnormal Paneth cell positioning in the crypt. We show here that Wnt-mediated up-regulation of EphB3 yields a similar Paneth cell phenotype, confirming a pivotal role for the EphB/ephrinB mutual repulsion system in defining cryptvillus architecture. Our results are also consistent with the notion that Apc mutant cells express the same genetic program as cells at positions 1-2 of the crypt (van de Wetering et al. 2002), with notable increases in EphB3, MMP7, and Pla2g2a being characteristic of both Paneth cells (Stappenbeck et al. 2003) and the Apc-deficient cells described here.

In summary, we have shown that Apc is a critical determinant of cell fate in the murine small intestinal epithelium. Acute activation of Wnt signaling immediately produces many of the phenotypes associated with early colorectal lesions: failed differentiation, increased proliferation, and aberrant migration. Within a short time scale, multiple processes are affected: interactions with the cellular matrix, interactions with the basement membrane, increased proliferation, and failure of positional cues (EphB/ephrinB).

At present, many different strategies are being pursued to identify the genes controlled by Wnt signaling. However, these models are necessarily constrained by the experimental systems used. For example, analysis of Wnt blockade within immortalized cells might not be predicted to precisely model active Wnt signaling in a physiological setting. The ability to acutely activate Wnt signaling in normal epithelial cells has allowed us for the first time to examine many of the proposed targets of Wnt signaling in vivo. Remarkably, given the diverse nature of the models studied, we can validate virtually all the previously reported Wnt targets in an in vivo set- 


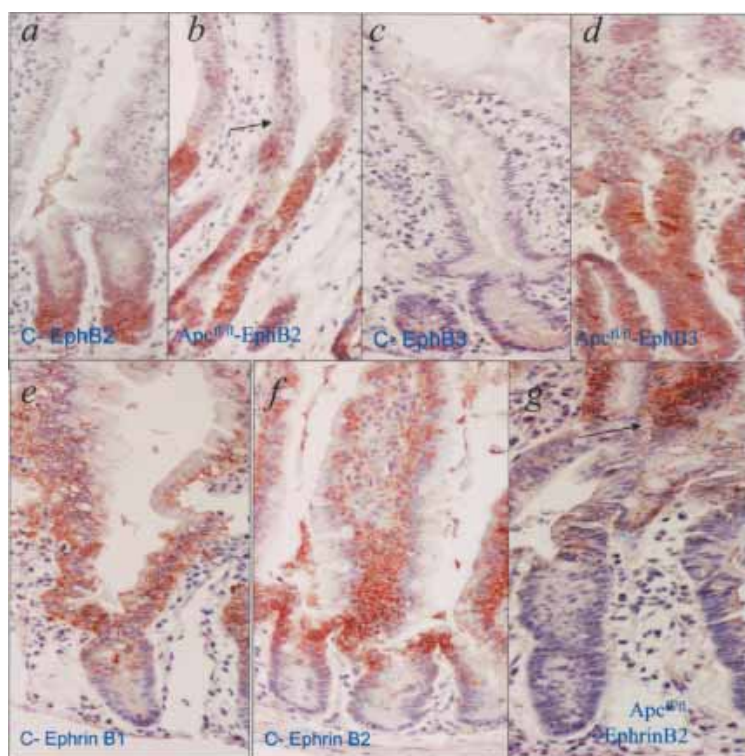

Figure 5. Perturbation of the EphB/ephrinB system. (a) The pattern of EphB2 staining in crypt enterocytes, predominantly confined to the lower half of control crypts. (b) EphB2 staining throughout the aberrant crypt structure in the induced $\mathrm{Cre}^{+} \mathrm{Apc} c^{1 / f 1}$ mice. Arrow denotes leading edge of aberrance, where unrecombined villus cells with wild-type morphology do not stain for EphB2. (c) EphB3 staining confined to the base of control crypts. (d) EphB3 staining throughout the aberrant crypt structure in the induced $\mathrm{Cre}^{+} \mathrm{Apc} c^{f l / f 1}$ mice. $(e, f)$ Ephrin $\mathrm{B} 1$ and $\mathrm{B} 2$ staining respectively of villus cells within control intestine. $(g)$ Lack of staining for Ephrin B2 within the aberrant cells in the induced $\mathrm{Cre}^{+} \mathrm{Apc} c^{f l / f 1}$ mice. Arrow denotes leading edge of aberrance, where unrecombined villus cells stain for Ephrin B2.

ting. Furthermore, we have been able to use our in vivo approach to identify many novel Wnt candidate target genes.

We have, therefore, identified a number of molecules that can be used as markers for loss of Apc and that thus represent potential targets for chemoprevention. Given our improved understanding of the role played by Apc in defining the normal differentiation and growth programs within the intestine, the challenge now is to determine how this data can be used for therapeutic and diagnostic purposes.

\section{Materials and methods}

\section{Mouse colony}

All experiments were performed according to UK Home Office regulations. Ahcre-positive mice were intercrossed with mice carrying a LoxP flanked Apc allele: $A p c^{580 s}$ (Shibata et al. 1997) and the Rosa26R reporter allele. Progeny from this cross were intercrossed to derive an outbred colony, segregating for the C57BL6/J, 129/Ola, and C3H genomes at a ratio of $75 \%, 12.5 \%$, and $12.5 \%$, respectively.

\section{$R T-P C R$}

RT-PCRs for Cre, Eb2, Sema3c, Pla2g2a, and TIAM1 were performed using the approach shown in Supplemental Material. Tissues were snap frozen, and RNA was extracted using the TRIzol method (Gibco).

\section{$\beta$-Galactosidase analysis}

To determine the pattern of recombination at the Rosa26R reporter locus, both whole mounts and sectioned material were analyzed as previously described (Ireland et al. 2004; see also Supplemental Material)
Tissue isolation

To induce recombination, mice were given daily intraperitoneal injections of $\beta$-napthoflavone $(80 \mathrm{mg} / \mathrm{kg})$. At each time point, mice were killed and the small intestine removed and flushed with water. Intestines were dissected as follows: The proximal $7 \mathrm{~cm}$ was mounted en face, fixed overnight in methacarn (methanol, chloroform, and acetic acid; 4:2:1 ratio), and paraffin embedded. The following $3 \mathrm{~cm}$ was opened and placed into RNA later (Sigma), ensuring that all mesentery and Peyers patches were removed. The following $5 \mathrm{~cm}$ was divided into $1-\mathrm{cm}$ lengths, bundled using surgical tape, and then fixed in $4 \%$ formaldehyde at $4^{\circ} \mathrm{C}$ for no more than $24 \mathrm{~h}$ before processing. Samples for Western analysis, frozen sections, and electron microscopy were then taken from the next $5 \mathrm{~cm}$ of intestine, and the remainder was fixed in methacarn.

Assaying apoptosis, mitosis, and S-phase labeling in vivo Apoptosis and mitotic index were scored from hematoxylin-and-eosinstained sections as previously described (Merritt et al. 1997). Apoptosis was independently confirmed by immunohistochemical staining with an antibody against active caspase 3 (1:750; R\&D systems; Marshman et al. 2001). For BrdU labeling, mice were injected with $0.25 \mathrm{~mL}$ of BrdU (Amersham), and staining was performed using an anti-BrdU antibody conjugate (Roche) at 1 part in 50 .

\section{Western analysis and immunohistochemistry}

For a detailed description, see Supplemental Material. Immunohistochemistry was performed according to Batlle et al. (2002), Kongkanuntn et al. (1999), and Van Noort et al. (2002); Western analysis was performed according to Hinck et al. (1994) and Van Noort et al. (2002).

\section{RNA extraction and array}

Eight-week-old male sibling mice were used for the array analysis. Three centimeters of the small intestine located $7 \mathrm{~cm}$ from the stomach was placed in RNAlater (after removing any mesentery and ensuring that no Peyers patches were present). The tissue was then homogenized in trizol reagent and RNA extracted using standard phenol-chloroform methodologies. Biotinylated target cRNA was generated according to http://www. paterson.man.ac.uk/facilities/mbcf/protocols.jsp. Affymetrix Gene Arrays were run at the Cancer Research UK facility at the Paterson Institute for Cancer Research. Raw signal intensities were initially screened using the MaxD/View-Program (http://www.bioinf.man.ac.uk/microarray/ $\operatorname{maxd} /$ index.html) to remove false-positive and false-negative signals (using a cutoff of at least one $p$ value for each transcript $<0.2$ ). The data was then normalized by global normalization, again using the MaxD/ViewProgram. Data was finally analyzed using the SAM-Program (Tusher et al. 2001). A $\delta$ value, which produced a false discovery rate of $5 \%$ was used to define the candidate genes. The output from this analysis therefore produces a ranked list of genes, of which the probability that each individual gene is deregulated is $95 \%$.

\section{Acknowledgments}

We thank Y. Hayes, M. van de Born, J. Meeldijk, L. Morris, N. Coleman, L. Sorokin, T. Sasaki, M. Kusakabe, C. Arnold, P. Cheng, and S.M. Bishop for supplying antibodies and assistance. This work was supported by Cancer Research UK, the Biotechnology and Biological Sciences Research Council, and the Wales Gene Park.

The publication costs of this article were defrayed in part by payment of page charges. This article must therefore be hereby marked "advertisement" in accordance with 18 USC section 1734 solely to indicate this fact.

\section{References}

Batlle, E., Henderson, J.T., Beghtel, H., van den Born, M.M., Sancho, E., Huls, G., Meeldijk, J., Robertson, J., van de Wetering, M., Pawson, T., et al. 2002. $\beta$-Catenin and TCF4 mediate cell positioning in the intestinal epithelium by controlling the expression of EphB/ephrinB. Cell 111: 251-263.

Bedi, A., Pasricha, P.J., Akhtar, A.J., Barber, J.P., Bedi, G.C., Giardiello, F.M., Zehnbauer, B.A., Hamilton, S.R., and Jones, R.J. 1995. Inhibition of apoptosis during development of colorectal cancer. Cancer Res. 55: 1811-1816. 
Bienz, M., and Clevers, H. 2000. Linking colorectal cancer to Wnt signaling. Cell 103: 311-320.

Fodde, R., Kuipers, J., Rosenberg, C., Smits, R., Kielman, M., Gaspar, C., van Es, J.H., Breukel, C., Wiegant, J., Giles, R.H., et al. 2001. Mutations in the APC tumor suppressor gene cause chromosomal instability. Nat. Cell. Biol. 3: 433-438.

Gallagher, R.C., Hay, T., Meniel, V., Naughton, C., Anderson, T.J., Shibata, H., Ito, M., Clevers, H., Noda, T., Sansom, O.J., et al. 2002. Inactivation of Apc perturbs mammary development, but only directly results in acanthoma in the context of Tcf-1 deficiency. Oncogene 21: 6446-6457.

Harada, N., Miyoshi, H., Murai, N., Oshima, H., Tamai, Y., Oshima, M., and Taketo, M.M. 2002. Lack of tumorigenesis in the mouse liver after adenovirus-mediated expression of a dominant stable mutant of ß-catenin. Cancer Res. 62: 1971-1977.

Hinck, L., Nathke, I.S., Papkoff, J., and Nelson, W.J. 1994. Dynamics of cadherin/catenin complex formation: Novel protein interactions and pathways of complex assembly. J. Cell. Biol. 125: 1327-1340.

Ireland, H., Kemp, R., Houghton, C., Howard, L., Clarke, A.R., Sansom, O.J., and Winton, D.J. 2004. Inducible Cre-mediated control of gene expression in the murine gastrointestinal tract: Effect of loss of $\beta$-catenin. Gasteroenterology 126: 1236-1246.

Kaplan, K.B., Burds, A.A., Swedlow, J.R., Bekir, S.S., Sorger, P.K., and Nathke, I.S. 2001. A role for the Adenomatous Polyposis Coli protein in chromosome segregation. Nat. Cell. Biol. 3: 429-432.

Kinzler, K.W. and Vogelstein, B. 1996. Lessons from hereditary colorectal cancer. Cell 87: 159-170.

Kinzler, K.W., Nilbert, M.C., Su, L.K., Vogelstein, B., Bryan, T.M., Levy, D.B., Smith, K.J., Preisinger, A.C., Hedge, P., McKechnie, D., et al. 1991. Identification of FAP locus genes from chromosome 5q21. Science 253: 661-665.

Kongkanuntn, R., Bubb, V.J., Sansom, O.J., Wyllie, A.H., Harrison, D.J., and Clarke, A.R. 1999. Dysregulated expression of $\beta$-catenin marks early neoplastic change in Apc mutant mice, but not all lesions arising in Msh2 deficient mice. Oncogene 18: 7219-7225.

Lustig, B., Jerchow, B., Sachs, M., Weiler, S., Pietsch, T., Karsten, U., van de Wetering, M., Clevers, H., Schlag, P.M., Birchmeier, W., et al. 2002. Negative feedback loop of Wnt signaling through upregulation of conductin/axin2 in colorectal and liver tumors. Mol. Cell. Biol. 22: $1184-1193$

Malliri, A., van der Kammen, R.A., Clark, K., van der Valk, M., Michiels, F., and Collard, J.G. 2002. Mice deficient in the Rac activator Tiam1 are resistant to Ras-induced skin tumors. Nature 417: 867-871.

Marshman, E., Ottewell, P.D., Potten, C.S., and Watson, A.J. 2001. Caspase activation during spontaneous and radiation-induced apoptosis in the murine intestine. J. Pathol. 195: 285-292.

Merritt, A.J., Allen, T.D., Potten, C.S., and Hickman, J.A. 1997. Apoptosis in small intestinal epithelial from p53-null mice: Evidence for a delayed, p53-independent G2/M-associated cell death after $\gamma$-irradiation. Oncogene 14: 2759-2766.

Morin, P.J., Sparks, A.B., Korinek, V., Barker, N., Clevers, H., Vogelstein, B., and Kinzler, K.W. 1997. Activation of $\beta$-catenin-Tcf signaling in colon cancer by mutations in $\beta$-catenin or APC. Science 275: $1787-$ 1790.

Näthke, I.S., Adams, C.L., Polakis, P., Sellin, J.H., and Nelson, W.J. 1996. The adenomatous polyposis involved in active cell migration. J. Cell. Biol. 134: 165-179.

Pelengaris, S., Khan, M., and Evan, G.I. 2002. Suppression of Myc-induced apoptosis in $\beta$ cells exposes multiple oncogenic properties of Myc and triggers carcinogenic progression. Cell 109: 321-324.

Potten, C.S., Booth, C., and Pritchard, D.M. 1997. The intestinal epithelial stem cell: The mucosal governor. Int. J. Exp. Pathol. 78: 219-243.

Probstmeier, R., Martini, R., and Schachner, M. 1990. Expression of J1/ Tenascin in the crypt-villus unit of adult mouse small intestineImplications for its role in epithelial cell shedding. Development 109: 313-321.

Shibata, H., Toyama, K., Shioya, H., Ito, M., Hirota, M., Hasegawa, S., Matsumoto, H., Takano, H., Akiyama, T., Toyoshima, K., et al. 1997. Rapid colorectal adenoma formation initiated by conditional targeting of the Apc gene. Science 278: 120-123.

Stappenbeck, T.S., Mills, J.C., and Gordon, J.I. 2003. Molecular features of adult mouse small intestinal epithelial progenitors. Proc. Nat1. Acad. Sci. 100: 1004-1009.
Tusher, V.G., Tibshirani, R., and Chu, G. 2001. Significance analysis of microarrays applied to the ionizing radiation response. Proc. Natl. Acad. Sci. 98: 5116-5121.

van de Wetering, M., Sancho, E., Verweij, C., de Lau, W., Oving, I., Hurlstone, A., van der Horn, K., Batlle, E., Coudreuse, D., Haramis, A.P., et al. 2002. The $\beta$-catenin/TCF-4 complex imposes a crypt progenitor phenotype on colorectal cancer cells. Cell 111: 241-250.

Van Noort, M., Meeldijk, J., van der Zee, R., Destree, O., and Clevers, H. 2002. Wnt signaling controls the phosphorylation status of $\beta$-catenin J. Biol. Chem. 277: 17901-17905.

Wong, M.H., Rubinfeld, B., and Gordon, J.I. 1998. Effects of forced expression of an NH2-terminal truncated $\beta$-Catenin on mouse intestinal epithelial homeostasis. J. Cell. Biol. 141: 765-777.

Wong, M.H., Huelsken, J., Birchmeier, W., and Gordon, J.I. 2002. Selection of multipotent stem cells during morphogenesis of small intestinal crypts of Lieberkuhn is perturbed by stimulation of Lef- $1 / \beta$ catenin signaling. J. Biol. Chem. 277: 15843-15850. 


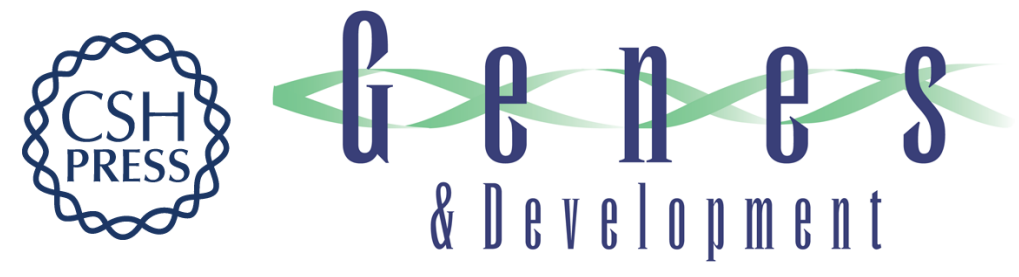

\section{Loss of Apc in vivo immediately perturbs Wnt signaling, differentiation, and migration}

Owen J. Sansom, Karen R. Reed, Anthony J. Hayes, et al.

Genes Dev. 2004, 18:

Access the most recent version at doi:10.1101/gad.287404

Supplemental http://genesdev.cshlp.org/content/suppl/2004/08/09/18.12.1385.DC1
Material

References This article cites 28 articles, 14 of which can be accessed free at:

http://genesdev.cshlp.org/content/18/12/1385.full.html\#ref-list-1

License

Email Alerting Receive free email alerts when new articles cite this article - sign up in the box at the top

Service right corner of the article or click here.

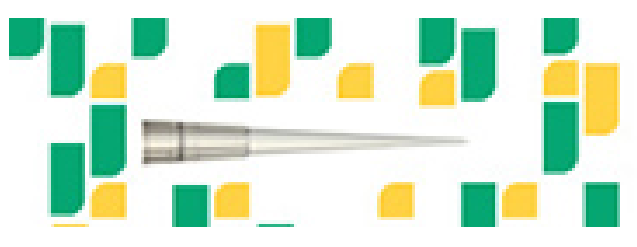

Focused on your science. 